\title{
Rekonsiliasi sebagai Proses Bersama Menyembuhkan Luka Sejarah Islam-Kristen di Kota Ambon
}

\author{
Rachel Iwamony \\ Fakultas Teologi Universitas Kristen Indonesia Maluku \\ iwamonyrachel07@yahoo.com \\ Tri Astuti Relmasira \\ Fakultas Teologi Universitas Kristen Indonesia Maluku \\ tutirrelmasir@yahoo.com
}

\begin{abstract}
Reconciliation between Muslims and Christians in Ambon City is an important process to know and study. In 1999-2004 Muslims and Christians got involved in religious-based social conflicts. The social conflicts have uprooted their brotherhood and sisterhood relationship, and left deep historical wounds. However, after a decade, Muslims and Christians in Ambon City have been successful in restoring their life in harmony and peace. Based on the interview with young people in several areas in Ambon City, it was found that reconciliation could be restored by realizing that both Muslim and Christian people should restore the social conflicts for the sake of their good future. They have restored the reconciliation between themselves by having social and religious activities. The process of reconciliation and religious dialogue may be seen as ways of healing the historical wounds of the past social conflicts.

[Rekonsiliasi antara Muslim dan Kristen di kota Ambon adalah sebuah proses penting untuk dikaji dan dipelajari. Pada tahun 1999-2004 Muslim dan Kristen terlibat dalam konflik sosial berlatarbelakang agama. Konflik sosial telah menghancurkan sendisendi hubungan persaudaraan mereka serta meninggalkan luka sejarah yang begitu dalam. Namun, setelah satu dekade, Muslim dan Kristen di Kota Ambon telah berhasil memulihkan kehidupan mereka dalam keharmonisan dan kedamaian. Dengan mewawancarai kalangan muda di beberapa daerah di Kota Ambon, terkuak bahwa rekonsiliasi terpulihkan dengan menyadari bahwa
\end{abstract}


orang-orang Muslim dan Kristen akan memulihkan konflik sosial demi masa depan mereka yang lebih baik. Mereka telah mewujudkan rekonsiliasi melalui kegiatan sosial dan keagamaan. Proses rekonsiliasi dan dialog keagamaan dapat dilihat sebagai cara untuk menyembuhkan luka historis dari konflik sosial di masa lalu.]

Keywords: reconciliation, interreligious relatiaonship, multiculturalism, dialogue, tolerance.

\section{Pendahuluan}

Sudah lebih dari satu dasawarsa, umat Islam dan Kristen di kota Ambon melewati konflik sosial berbasis agama, yang terjadi pada tahun 1999-2004. Pada akhirnya mereka telah berhasil membangun kehidupan yang harmonis, rukun, aman, dan damai. Pencapaian ini merupakan upaya bersama seluruh masyarakat kota Ambon dalam menata kehidupan mereka yang hancur akibat konflik sosial itu. Dengan kata lain, realita kehidupan masyarakat kota Ambon yang rukun, aman, dan damai itu mencerminkan suatu kesadaran bersama, tentang pentingnya kehidupan yang harmonis. Keberhasilan mereka memperbaiki hubungan Islam-Kristen yang rusak akibat konflik sosial itu, merupakan hal penting untuk diteliti. Melalui wawancara, penelitian ini dilakukan terhadap beberapa pemuda, baik dari kalangan Islam maupun Kristen, untuk mengetahui bagaimana proses-proses rekonsiliasi yang dilakukan oleh masyarakat kota Ambon, khususnya Islam dan Kristen. Oleh karena itu, artikel ini disusun dengan menggunakan analisis kualiatif deskriptif, yang dilakukan terhadap tanggapan para pemuda terkait proses rekonsiliasi Islam Kristen di kota Ambon. Para pemuda dipilih sebagai kelompok yang diwawancarai, sebab pada satu sisi mereka adalah kelompok yang sangat rentan dan mudah terprovokasi isu-isu negatif, tetapi pada sisi yang lain mereka juga adalah penggerak-penggerak utama rekonsiliasi dalam masyarakat.

Penelitian ini dilakukan di beberapa wilayah di kota Ambon yang mengalami konflik, juga wilayah yang tidak mengalami konflik. Dari pertimbangan itu, ada dua kategori lokasi penelitian. Pertama, wilayah di 
mana mayoritas penduduknya beragama Islam atau Kristen. Kedua, wilayah di mana penduduknya tidak didominasi oleh agama tertentu. Wilayah untuk kategori pertama yang mayoritas penduduknya beragama Islam adalah Waringin, sedangkan wilayah yang mayoritasnya beragama Kristen adalah Kudamati. Selain itu, desa Hunut-Durian Patah dijadikan lokasi penelitian, sebab desa ini merupakan sebuah desa, di mana bagian barat desa ditempati oleh penduduk yang beragama Kristen, sedangkan bagian timur ditempati oleh penduduk yang beragama Islam. Untuk kategori wilayah yang tidak terlibat konflik, serta pendudukya tidak didominasi agama tertentu, dipilih desa Wayame.

\section{Upaya-Upaya Rekonsiliasi}

Terjadinya rekonsiliasi antara umat Islam dan Kristen di kota Ambon merupakan proses yang tidak mudah. Dikatakan sebagai proses yang tidak mudah, sebab mereka yang melaksanakan proses-proses rekonsiliasi itu adalah juga mereka yang menjadi korban dari konflik sosial tersebut. Ada banyak fakta yang dikemukakan oleh para pemuda terkait proses-proses rekonsiliasi yang terjadi. Salah satu yang disebutkan oleh sebagian besar pemuda adalah telah terjadi interaksi yang baik antara umat Islam dengan umat Kristen. Seorang pemuda bernama Vence mengatakan, "Menurut saya, untuk saat ini, hubugan antara Islam dengan Kristen sudah aman, rukun, dan damai. Ukurannya, mereka sudah mulai saling berinteraksi, saling menghormati dan menghargai satu dengan yang lain." Pernyataan "sudah aman, rukun, dan damai" yang disampaikan pemuda tersebut mempertegas perkembangan perubahan relasi umat Islam dan umat Kristen yang terganggu selama konflik sosial itu.

Sebagaimana diketahui secara umum, selama konflik sosial yang terjadi di Ambon tidak terjadi interaksi antara umat Islam dan umat Kristen. Pada saat itu, pemukiman dibangun secara terpisah atau tersegregasi. Pelayanan-pelayanan publik juga dilakukan secara terpisah. Proses pendidikan, perkantoran, pasar, bahkan pelayanan rumah sakit dilakukan secara terpisah berdasarkan wilayah tempat tinggal. Pada satu

${ }^{1}$ Vence (29 tahun), Wawancara, Wayame-Ambon, 12 Juli 2016. 
sisi, praktik seperti itu menjadi pilihan yang tepat sesuai konteks pada waktu itu untuk mencegah terjadi konflik. Namun pada sisi yang lain, umat Islam dan umat Kristen dibawa untuk mengalami bahwa mereka akan hidup aman apabila mereka tinggal terpisah. Akibatnya, terjadi pemisahan dalam kehidupan bermasyarakat berdasarkan agama yang dianut. Segregasi pemukiman berdasarkan agama yang dianut seseorang menjadi salah satu ciri pemukiman di kota Ambon. Penduduk wilayah tertentu didominasi oleh penganut agama tertentu. Artinya, tempat tinggal seseorang menunjukkan agama yang dianutnya. Contohnya, ketika seseorang menyebut Kudamati sebagai tempat tinggalnya, maka secara langsung orang mengetahui bahwa dia beragama Kristen. Demikian juga, ketika Waringin disebut sebagai tempat tinggal, maka orang mengetahui secara langsung bahwa orang itu beragama Islam. Menurut Vence, sekalipun segregasi pemukiman masih ada, namun telah terjadi interaksi yang baik antara Islam Kristen. Aktifitas pendidikan, perkantoran, pasar, dan rumah sakit telah dilakukan secara bersamasama. Dengan kata lain, tidak ada lagi pemisahan pelayanan publik. Inilah yang menjadi ukuran Vence untuk menilai positif hubungan Islam Kristen di kota Ambon pada masa sekarang. Sekalipun pandangan ini menggembirakan, fakta segregasi pemukiman masih menjadi salah satu faktor yang harus disikapi secara serius, sebab pada hakikatnya segregasi pemukiman menunjukkan sikap menghindari kontak langsung dengan umat beragama lain.

Menariknya, dalam pandangan Vence, interaksi itu terjadi karena mereka saling menghormati dan menghargai. Dalam hal ini, interaksi dipahami sebagai pertemuan antara dua pihak, di mana kedua belah pihak saling menerima keberadaan mereka masing-masing. Umat Islam bersedia menerima keberadaan umat Kristen, baik dalam perjumpaan sehari-hari di kantor, di sekolah, di Rumah Sakit, maupun perjumpaan di pasar. Jadi, nilai dasar dari interaksi ini adalah terjadi dialog kehidupan. ${ }^{2}$

²Olaf Schumann, Dialog Antar Umat Beragama (Jakarta: BPK Gunung Mulia, 2009), 300. 
Dialog kehidupan itu tidak dapat terjadi apabila hanya satu pihak yang menginginkan dan menciptakannya.

Dialog kehidupan terjadi, ketika kedua pihak memiliki kesadaran bersama, untuk bertemu, bertatap muka, dan berbicara secara bersamasama tentang kehidupan mereka bersama. Prinsip dialog seperti ini sebagaimana dikatakan Dubut:

"Dialog adalah belajar memahamai orang lain, belajar hidup bersama orang lain, dan membangun kebersamaan dengan orang lain, bahkan belajar dari kekayaan kerohanian orang lain. Sebagai sebuah proses belajar, maka dialog tidak akan pernah selesai. Sebab itu, dialog adalah sebuah gaya hidup yang niscaya dalam masyarakat Indonesia yang tingkat pluralitasnya sangat tinggi. Sebab itu, dialog bukanlah mencari-cari kesamaan dan persamaan, tetapi dialog adalah membangun kebersamaan dari perbedaan." ${ }^{3}$

Pandangan ini menegaskan suatu pemikiran mendasar, bahwa rekonsiliasi Islam dan Kristen merupakan tanggungjawab bersama untuk diciptaan; bukan sesuatu yang alamiah ada dengan sendirinya. Indikator penilaian yang hampir sama dikemukakan oleh Deny, ia mengatakan: "Sudah tidak ada lagi batas-batas yang harus ditakuti untuk masuk ke daerah-daerah tertentu, baik Islam maupun Kristen." ${ }^{4}$ Pernyataan pemuda ini menunjukkan bahwa Islam dan Kristen telah berhasil keluar dari rasa nyaman dalam ketakutan mereka. Dengan mengalahkan ketakutan mereka, mereka telah mampu bertemu dengan "yang lain" di luar wilayah amannya. Oleh karena itu, dapat dikatakan bahwa pemeluk agama Islam dan Kristen di Ambon sudah berani menarik zona amannya; menjangkau wilayah yang sebelumnya dianggap mengancam hidupnya. Umat Islam tidak lagi menjadi ancaman bagi umat Kristen dan sebaliknya, umat Kristen bukan lagi ancaman bagi umat Islam. Proses hidup yang sedemikian ini menunjukkan proses-proses membangun rekonsiliasi di antara mereka. Tentang rekonsiliasi ini, muncul pertanyaan

${ }^{3}$ Darius Dubut, "Dari Perbedaan Menuju kebersamaan," dalam Merayakan Kebebasan Beragama: Bunga Rampai 70 Tabun Djohan Effendi, ed. Elza Peldi Taher (Jakarta: ICRP dan Kompas, 2009), 499.

${ }^{4}$ Deny (27 tahun), Wawancara, Kudamati-Ambon, 21 Juni 2016. 
penting: apakah umat Islam dan umat Kristen di Ambon telah melupakan segala kepahitan yang dialami selama konflik? Untuk menjawab pertanyaan ini, pikiran Haryanto patut diperhatikan. Ia mengatakan: "Pengampunan menuju rekonsiliasi bukanlah usaha mengesampingkan atau menghapus suatu kenangan pahit dan fakta yang menyakitkan hati, melainkan suatu tekad untuk menciptakan hubungan baru antarmanusia menuju damai dan sejahtera; terdorong oleh cita-cita membangun masa depan yang lebih baik. ${ }^{5}$ Dengan memperhatikan apa yang dikatakan Haryanto, dapat dikatakan bahwa nampaknya bagi umat Islam dan umat Kristen di kota Ambon, peristiwa kelam yang mereka alami telah menjadi bagian penting dari sejarah hidup mereka. Namun, sejarah pahit itu tidak harus menjadi penghalang bagi mereka untuk bergerak bersama membangun masa depan bersama menjadi lebih baik. Penerimaan terhadap pengalaman pahit telah melahirkan kesadaran bersama untuk memperbaiki hubungan yang terganggu tersebut. Ini adalah salah satu hakikat mendasar dari rekonsiliasi, yaitu berdamai dengan masa lampau yang pahit dan kelam.

Sikap saling menerima itu didorong oleh sikap saling menghormati dan menghargai. Nilai dasar dari kedua sikap yang disebutkan terakhir ini adalah, bahwa umat Islam melihat umat Kristen memiliki martabat yang sama dengan umat Islam; begitu pula sebaliknya umat Kristen melihat umat Islam. Tidak ada lagi keinginan untuk saling menghancurkan dan membinasakan. Bahkan, sikap menghormati dan menghargai itu juga diperluas pada pengakuan terhadap kebenaran dan otoritas agama masing-masing. Kehidupan keagamaan seperti ini mencerminkan prinsip dasar dari hakikat agama bagi hidup manusia. Hal ini seperti yang dikatakan Schuman, "Jadi, agama yang mempertahankan primordialisme yang eksklusif itu tak berdaya sama sekali dalam usaha rekonsiliasi. Semua usaha rekonsiliasi akan gagal selama agama, atau lebih tepat

${ }^{5}$ Ignatius Haryanto dan Pax Benedanto, Terbuka terbadap Sesama Umat Beragama (Yogyakarta: Kanisius, 2004), 67-68. 
manusia yang beragama, tidak mampu melihat citra kemanusiaan juga dalam diri orang lain, walaupun orang itu adalah musuhnya sekalipun. ${ }^{6}$

Fakta tentang sikap saling menerima itu tercermin dalam realita hidup sehari-hari Islam Kristen. Di Kota Ambon pada waktu sekarang, ketika umat Islam mau merayakan hari raya Idul Fitri, para pemuda Kristen terlibat menjaga masjid-masjid maupun tempat-tempat umum, di mana diselenggarakan Salat bersama. Demikian juga ketika umat Kristen merayakan Natal, baik ibadah Malam Natal tanggal 24 Desember, maupun ibadah Natal tanggal 25 Desember, gedung-gedung gereja dijaga oleh pemuda Islam. ${ }^{7}$ Perilaku-perilaku sedemikian ini terjadi karena ada sikap saling menghormati dan menghargai. Penghormatan dan penghargaan itu menjadi kekuatan bagi umat Islam dan umat Kristen untuk melawan sikap agresi ${ }^{8}$ dan perlawanan yang membuat konflik sosial terjadi di kota Ambon. Praktik hidup yang sekarang dibangun oleh umat Islam dan Kristen di kota Ambon, menunjukkan penerimaan yang tulus terhadap perbedaan-perbedaan keagamaan yang ada pada tiap agama. Dengan demikian, umat Islam dan umat Kristen tidak lagi melihat perbedaan-perbedaan dalam hidup keagamaan, sebagai tantangan dan ancaman, tetapi sebagai kekuatan yang mendukung kerjasama yang baik dan produktif. ${ }^{9}$

Perkembangan dalam membangun relasi yang baik itu bukan merupakan suatu situasi yang terjadi dengan sendirinya. Berbagai proses keagamaan dan sosial tercipta untuk membangun kebersamaan hidup dan menghilangkan kecurigaan serta dendam. Hal ini seperti dikatakan oleh Bram, "Hubungan Islam-Kristen sudah mulai bagus. Alasannya,

${ }^{6}$ Olaf Schumann, Agama-agama: Kekerasan dan Perdamaian (Jakarta: BPK Gunung Mulia, 2011), 485.

${ }^{7}$ Praktik ini muncul setelah konflik sosial terjadi di Ambon tahun 1999-2004.

${ }^{8}$ Erich Fromm menjelaskan bahwa kadang manusia menunjukkan sikap agresi sebagai tindakan mempertahankan diri dari serangan lawan. Penjelasan tentang sikap agresi yang dilakukan oleh Fromn membantu kita untuk mengerti kembali apa yang terjadi dalam konflik Ambon tahun 1999-204. Sikap agresif itu diperlihatkan baik oleh umat Islam maupun umat Kristen. Lihat Ercih Fromn, Akar Kekerasan: Analisis Sosio-Psikologis atas Watak Manusia (Yogyakarta: Pustaka Pelajar, 2010), XI.

${ }^{9}$ Djohan Effendi, Pluralisme dan Kebebasan Beragama (Yogyakarta: Interfidei, 2011), 49-50. 
karena sudah ada interaksi yang baik antara orang Islam dan Kristen di Kota Ambon, misalnya di pasar dan aktifitas yang lain. Orang Kristen tidak lagi takut datang ke wilayah Islam dan sebaliknya; ada kegiatan bersama antara Islam dan Kristen dalam kegiatan keagamaan dan sosial." ${ }^{10}$ Penyebutan kegiatan keagamaan sebagai kegiatan bersama umat Islam dan Kristen menunjuk kepada pelaksanaan MTQ pada tahun 2013 dan Pesta Paduan Suara Gerejawi (biasanya disingkat PESPARAWI) pada tahun 2015 di kota Ambon. Di Maluku pada umumnya dan di kota Ambon pada khusus, dua kegiatan keagamaan ini menyatukan umat Islam dan Kristen dalam pengorganisasian hingga pelaksanaan kegiatankegiatan keagamaan tersebut. Pada saat pelaksanaan MTQ, umat Kristen terlibat secara penuh, antara lain dalam bentuk menyediakan rumahrumah mereka sebagai tempat tinggal bagi peserta MTQ. Demikian juga pada saat pelaksanaan PESPARAWI Nasional, umat Islam menyediakan rumah-rumah mereka sebagai tempat tinggal peserta PESPARAWI. Kebersamaan dalam menyelenggarakan kegiatan keagamaan memberi dampak yang sangat positif dalam hal membangun kebersamaan hidup lintas agama, sebab dalam perisitwa-peristiwa keagamaan seperti ini mereka berbagi beban, sukacita, dan kebahagiaan hidup. Sekalipun Bram tidak secara eksplisit menyebutkan bentuk kegiatan sosial yang terjadi, pemuda lain yang bernama Madi menyebutkan secara tegas aktifitas sosial yang dilakukan secara bersama-sama. "Kami dengan saudarasaudara di RT/RW 04-03 yang mayoritas beragama Kristen selalu bekerja sama membersihkan lingkungan; juga menjaga keamanan secara bersama-sama. Hal ini membuat relasi kami yang terganggu waktu terjadi konfik, sudah menjadi baik."11

Pandangan dua pemuda ini menegaskan bahwa praktik-praktik hidup yang selalu mempertemukan pihak-pihak yang pernah mengalami konflik merupakan proses-proses rekonsiliasi yang dibangun oleh masyarakat akar rumput atau grassroots. Bahkan dengan praktik membangun kebersamaan hidup dalam aspek-aspek keagamaan, akan

${ }^{10}$ Bram (35 tahun), Wawancara, Kudamati-Ambon, 22 Juni 2016.

${ }^{11}$ Madi (32 tahun), Wawancara, Waringin-Ambon, 6 Juni 2016. 
mampu membuat mereka bersama-sama menyembuhkan sejarah kelam yang pernah mereka alami bersama. Ini merupakan rekonsiliasi yang sejati dan sesungguhnya, sebab perjumpaan dalam membangun hidup secara bersama-sama dilakukan oleh mereka yang sama-sama terluka. Artinya, orang-orang yang mengalami konflik sosial itu sendiri yang aktif mengupayakan rekonsiliasi. Rekonsiliasi yang diupayakan sedemikian ini memiliki kekuatan permanen dibanding upaya rekonsiliasi dari pihak luar, termasuk pihak pemerintah. Dorongan untuk membangun kebersamaan hidup dalam bentuk gotong royang yang diprogramkan oleh para penguasa cenderung tidak memberi manfaat yang berarti bagi masyarakat, karena kepentingan penguasa yang diutamakan. ${ }^{12}$ Oleh karena itu, proses-proses rekonsiliasi yang terbagun dari inisiatif masyarakat akar rumput merupakan bentuk rekonsiliasi murni. Dengan demikian, dapat dikatakan bahwa baik umat Islam maupun Kristen di kota Ambon sedang bekerja bersama agar konflik sosial itu tidak boleh terjadi lagi dalam kehidupan mereka. Prinsip rekonsiliasi sedemikian inilah yang dicatat Umar dalam artikelnya bahwa, "Dalam upaya mencegah berulangnya konflik sosial yang terjadi, penyelesaian konflik atau resolusi harus dilakukan dengan menggunakan berbagai pendekatan secara komprehensif-holistik. Cara tersebut adalah dengan memelihara perdamaian (peace keeping), mendorong transisi dan transformasi konflik dengan upaya membentuk perdamaian (peace making), serta mendorong rekonsiliasi dengan membangun perdamaian (peacebuilding)". ${ }^{13}$

Baiknya relasi umat beragama, khususnya Islam dan Kristen di kota Ambon juga dikatakan oleh Syarul, "Hubungan kita baik-baik dan amanaman saja, hanya saja kita terlalu terpengaruh oleh provokasi-provokasi yang dapat menghancurkan kita bersama."14 Pemuda ini menunjukkan sisi lain dari kehidupan umat Islam dan Kristen di kota Ambon, bahwa sekalipun relasi mereka itu sudah baik, tetapi masih ada orang yang

${ }^{12}$ Olaf Schumann, Menghadapi Tantangan, Memperjuangkan Kerukunan Jakarta: BPK Gunung Mulia, 2006), 35.

${ }^{13}$ Nasaruddin Umar, "Interfaith Dialog dalam Mengembangkan Kehidupan Beragama yang Harmoni dan Damai" Jurnal Bimas Islam 6, no. 3 (2013): 630.

${ }^{14}$ Syarul (30 tahun), Wawancara, Hunut-Durian Patah-Ambon, 5 Juli 2016. 
mudah terpengaruh isu-isu provokatif. Sikap inilah yang patut disadari untuk dikelola dan diminimalkan, sehingga tidak menjadi potensi konflik baru dalam kehidupan bermasyarakat. Tentang sikap mudah terpengaruh oleh isu provokatif, John memiliki pandangan bahwa masyarakat Ambon sudah tidak mudah menanggapi isu-isu negatif, ia menyatakan, "Orang sudah tidak mudah dipengaruhi isu dan orang sudah tidak ada saling curiga." 15 Pandangan ini menunjukkan penilaian yang berbeda tentang sikap masyarakat kota Ambon menyikapi isu provokatif. Perbedaan itu menggambarkan realita sesungguhnya bahwa ada masyarakat yang masih mudah dipengaruhi isu, tetapi juga ada orang yang memiliki sikap kritis terhadap isu. Hal lain yang menjadi indikasi bahwa umat Islam dan Kristen di kota Ambon sedang dalam proses bersama membangun rekonsiliasi adalah tidak ada lagi kecurigaan satu terhadap yaang lain. "Tidak ada lagi saling curiga. Saya membuka bengkel dan biasanya orangorang dari sebelah, yaitu orang Kristen dari Hunut datang memperbaiki motor di bengkel saya," tutur Udin. ${ }^{16}$

Disadari bahwa proses rekonsiliasi yang dibangun oleh umat Islam dan Kristen kota Ambon masih mengalami berbagai macam tantangan dan ancaman. Hal ini disebabkan karena masih ada sebagian kecil masyarakat yang memiliki persepsi negatif terhadap hubungan antara umat Islam dan Kristen di kota Ambon. Persepsi yang negatif itu juga tercermin dalam sikap takut memasuki daerah yang dominasi penduduknya beragama tertentu. George mengatakan, "Hubungan Islam-Kristen tidak begitu akur. Kedua bela pihak tidak begitu berani untuk memasuki daerah yang berbeda. Islam takut masuk daerah Kristen dan sebaliknya. Hal ini bisa terjadi konflik." "17 Ketakutan memasuki daerah tertentu menunjukkan bahwa ada masyarakat kota Ambon yang masih belum mampu menghapus memori negatif dari ingatan mereka. Ini berarti di kota Ambon ada orang yang memiliki sikap traumatis yang disebabkan oleh ingatan terhadap konflik sosial itu. Memori negatif itu

\footnotetext{
15John (35 tahun), Wawancara, Kudamati-Ambon, 22 Juni 2016.

${ }^{16}$ Udin (35 tahun), Wawancara, Hanut-Durian Patah-Ambon, 4 Juli 2016.

${ }^{17}$ George (25 tahun), Wawancara, Kudamati-Ambon, 23 Juni 2016.
} 
masih sering nampak dalam menyikapi informasi tertentu. Hal ini juga ditegaskan Axel, "Hubungan Islam-Kristen belum cukup baik. Karena kalau mendengar isu yang belum jelas dari mana, orang sudah bertindak semaunya yang dapat menimbulkan konflik." 18 Penilaian negatif dengan mengacuh pada segregasi wilayah pemukiman juga dikemukakan oleh Renfy, "Saya belum bisa jamin kalau relasi orang Islam dengan orang Kristen di kota Ambon sudah baik 100\%. Alasannya adalah karena kita masing-masing sudah hidup pada wilayah masing-masing. Hingga kini, masih ada keraguan kedua komunitas untuk lama-lama di satu wilayah. Hal lain, kita semua yang melihat dan merasakan jadi korban kerusuhan kemarin; jadi pasti saja ada dendam. Jadi saya belum yakin kalau hubungan orang Islam dengan Kristen sudah benar-benar aman."19 Apa yang dikatakan oleh Renfy ini menunjukkan bahwa ia belum bisa keluar dari bayang-bayang pengalaman masa konflik sosial yang sulit. Rasa sakit itu masih dirasakan dan belum ditransformasi sebagai pengalaman buruk di masa lampau yang harus ditinggalkan. Oleh karena itu, dendam masih terpikirkan.

Pikiran yang hampir sama juga diungkapkan oleh Jhon, "Pandangan sosial yang terbaca, relasi antar umat Muslim dan Kristen di kota Ambon saat ini belum sepenuhnya membaik. Memang proses saling menerima itu sudah terjadi, tetapi letak penduduk masih dalam perkotakan, sehingga belum sepenuhnya pulih. Mengapa dikatakan demikian? Contoh saja bisa kita ambil dari lingkungan tempat tinggal kita di desa Hunuth. Di sini, kita tinggal dengan masyarakat yang majemuk, ada Islam dan ada Kristen. Apa yang terjadi sampai saat ini, masih sering terjadi perkelahian antara pemuda Islam dan Kristen. Dari situ, mengapa saya mengatakan bahwa relasi Islam Kristen di kota Ambon saat ini belum terlalu sepenuhnya baik." ${ }^{20}$ Pemuda ini masih melihat bahwa relasi umat Islam dengan umat Kristen belum sepenuhnya baik, karena masih sangat sering terjadi perkelahian antara pemuda yang beragama Islam dengan pemuda

\footnotetext{
${ }^{18}$ Axel (29 tahun), Wawancara, Hunut-Durian Patah-Ambon, 6 Juni 2016.

${ }^{19}$ Renfy (28 tahun), Wawancara, Kudamati-Ambon, 23 Juni 2016.

20Jhon (26 tahun), Wawancara, Hunut-Durian Patah-Ambon, 7 Juli 2016.
} 
yang beragama Kristen. Dalam hal ini, ia melihat orang-orang yang terlibat perkelahian berhubungan dengan agama mereka. Padahal, biasanya mereka berkelahi bukan karena agama. Pandangan pemuda ini masih mewakili cara berpikir sempit yang berkembang pada saat terjadi konflik sosial di Ambon. Pada waktu itu, ketika terjadi perkelahian atau keributan antar individu, maka orang tidak berusaha untuk menemukan alasan yang mendorong mereka berkelahi, tetapi orang akan melihat pada agama apa yang dianut oleh indivdu-individu yang terlibat perkelahian itu. Akibatnya, ketika terdengar ada perkelahian antar dua orang yang berbeda agama, maka akan menyebabkan tindakan kekerasan terjadi di lain tempat. Cara berpikir ini sangatlah keliru dan berbahaya, terutama dalam masyarakat majemuk yang pernah mengalami konflik sosial yang cukup serius. Karena itu, perlu pendampingan kepada mereka yang masih memiliki cara berpikir sempit tersebut. Pendampingan harus dilakukan oleh baik pemerintah maupun tokoh-tokoh agama untuk mengubah cara berpikir yang keliruh itu.

Hal penting yang patut dicatat dari para pemuda yang memiliki persepsi negatif terhadap hubungan Islam-Kristen di kota Ambon, ada seorang pemuda yang mengatakan bahwa jika orang Islam dan Kristen menjalankan ajaran agama masing-masing dengan baik dan benar, maka mereka tidak akan terlibat konflik. Ia katakan, "Hubungan Islam-Kristen di Ambon masih sering diwarnai konflik. Oleh karena itu, untuk bisa menjadi lebih baik lagi, kedua belah pihak harus bisa tahu dan menjalankan ajaran agama masing-masing. Karena tidak ada agama yang mengajarkan pemeluknya untuk melakukan kejahatan. Kalau kedua belah pihak menjalankan ajaran agama dengan benar, maka tidak lagi ada kekacauan di kota Ambon." ${ }^{21}$ Pemuda ini menarik akar konflik yang melibatkan pemeluk agama pada ketidaktahuan orang beragama tentang ajaran agama itu. Menurut dia, kebodohan tentang agama yang menjadi penyebab konflik sosial antar umat beragama. Ketidaktahuan tentang agama menyebabkan agama menjadi sumber masalah dan konflik; agama

${ }^{21}$ Agung (26 tahun), Wawancara, Hunut-Durian Patah-Ambon, 6 Juli 2016. 
menyemburkan kebencian, dendam, dan lain-lain. ${ }^{22}$ Penilaian yang sama juga dikatakan oleh Kevin dan Budi bahwa sangat sering terjadi, mereka yang berkelahi membelah agama mereka, adalah orang-orang yang sesungguhnya tidak mengerti agama mereka. ${ }^{23}$ Argumen bahwa konflik antaragama dipicuh oleh orang-orang yang tidak mengerti agamanya dikemukakan juga oleh Khotimah dalam sebuah artikelnya:

"Secara mendetail, faktor-faktor terjadinya ketidakharmonisan dan konflik antaragama pada umumnya hampir dapat diketahui, baik dari sisi teoretis maupun kenyataan praktis yang terjadi. Dari faktor-faktor itu, dapat diketahui, paling tidak, bahwa akar permasalahan terjadinya konflik antarumat beragama adalah tidak adanya kesadaran beragama yang bersumberkan dari ketidaktahuan atau kekurangpahaman terhadap agamanya sendiri, terlebih agama orang lain." 24

Dalam pandangannya ini, Khotimah menunjukkan bahwa hal penting yang masih harus menjadi perhatian seluruh agama adalah peningkatan pengetahuan penganutnya terhadap agamanya. Artinya, jika seluruh umat beragama sama-sama memiliki komitmen untuk mencegah konflik antaragama, maka pengetahuan yang benar dan baik tentang agamanya patut dimiliki.

Ketiga pemuda yang baru disebutkan di atas, memiliki pandangan yang khas dibanding pemuda-pemuda lain, sebab mereka tidak melihat agama sebagai pemicuh konflik. Sebaliknya, mereka melihat agama sebagai salah satu sumber perdamaian antaragama. Bagi mereka, setiap agama mengajarkan pemeluknya tentang kebaikan. Karena itu, mereka yang berkonflik itu tidak mengerti agamanya. Para pemuda ini melihat sisi positif dari agama. Sisi positif agama ini yang diuraikan oleh $\mathrm{Al}$ Qurtuby dengan menyatakan:

\footnotetext{
${ }^{22}$ Frans Magnis Suseno, "Keagamaan Masa Depan," dalam Spiritualitas Agama-agama untuk Keadilan dan Perdamaian, ed. Indro Suprobo (Yogyakarta: Interfidei, 2011), 57-58.

${ }^{23}$ Kevin (30 tahun) dan Budi (31 tahun), Wawancara, Wayame-Ambon, 13 Juli 2016.

${ }^{24}$ Khotimah, "Dialog dan Kerukunan Antar Umat Beragama," Jurnal Ushuluddin 17, no. 2 (Juli 2001): 216, http//dx.doi.org/10.24014/jush.v17i2.693.
} 
"Agama bisa melahirkan tindakan kemanusiaan yang positif karena ia bisa menjadi "sumber makna" dan kebijakan (a source of meaning and wisdom). Agama menanamkan kepada para pemeluknya apa yang oleh antropolog Clifford Geertz disebut "vitalitas moral" yang hadir karena manusia (para pemeluk agama) yakin dan komitmen pada esensi "Realitas yang fundamental". Keyakinan pada "Realitas yang fundamental" inilah yang menjadikan agama bisa menjadi "sumber makna" bagi pemeluknya yang pada gilirannya mampu menjadi kekuatan penggerak aksi-aksi kemanusiaan yang berbudaya dan beradab. $" 25$

Nampak dalam tulisannya ini, Al Qurtuby meyakini bahwa agama seharusnya menjadi sumber inspirasi dan kekuatan yang menggerakan manusia (para pemeluknya) melakukan tindakan-tindakan yang bermanfaat untuk membangun hidup dan masyarakatnya. Keyakinan seperti ini juga yang dimiliki oleh ketiga pemuda di atas dengan mengatakan bahwa mereka yang berkelahi untuk membela agama mereka, sesungguhnya tidak mengerti agama mereka. Karena itu, dapat dikatakan bahwa orang yang berkelahi demi membela agama mereka, tanpa disadari, mempermalukan agama itu sendiri.

Ada beberapa faktor yang dikemukakan oleh para pemuda sebagai faktor-faktor yang mempengaruhi upaya-upaya rekonsiliasi umat Islam dan Kristen di kota Ambon. Faktor ekonomi merupakan salah satu alasan pendorong masyarakat kota Ambon memperbaiki dan menjaga hubungan baik antaragama, lebih khusus, antara Islam dan Kristen. "Faktor ekonomi sangat mempengaruhi kesadaran kita bahwa tidak perlu bermusuhan. Jikalau situasi tidak aman, maka orang susah beraktifitas. Saya sendiri merasakan hal ini," kata Machmud. ${ }^{26}$ Pandangan ini dapat dimengerti karena sebagai tukang ojek, ia membutuhkan situasi aman yang memungkinkan pekerjaan yang ia jalani berlangsung dengan baik. Artinya, ia membutuhkan pelanggan yang tidak saja berasal dari kalangan

\footnotetext{
${ }^{25}$ Sumanto Al-Qurtuby, 'Pluralisme, Dialog, dan Peacebuilding Berbasis Agama di Indonesia," dalam Merayakan Kebebasan Beragama: Bunga Rampai 70 Tabun Djoban Effendi, ed. Elza Peldi Taher (Jakarta: ICRP dan Kompas, 2009), 178-179.

${ }^{26}$ Machmud (25 tahun), Wawancara, Waringin-Ambon, 8 Juni 2016.
} 
Muslim tetapi juga dari kalangan Kristen, bahkan siapapun dan apapun agamanya.

Selain faktor ekonomi, Deny menyebutkan masa depan yang baik bagi para pemuda sebagai faktor lain yang juga berpengaruh mendorong terciptanya hubungan yang baik antara umat Islam dan Kristen di kota Ambon. Ia berkata:

"Relasi Islam-Kristen di Ambon saat ini sudah jauh lebih baik. Mengapa dikatakan demikian? Karena dua hal. Pertama, kalau dilihat dari kondisi kota Ambon yang sekarang, sudah sangat baik pasca tragedi antar dua umat beragama ini beberapa tahun lalu. Sekarang, umat Islam dan Kristen tidak mau berada pada masamasa sulit seperti itu lagi, masa di mana orang tidak bisa bebas beraktifitas, dan lainnya. Kedua, pemuda Islam dan Kristen sekarang fokusnya sama, yaitu punya masa depan yang cerah. Dari tujuan itu membuat mereka bersatu untuk bekerja sama. Mereka harus kuliah, berarti butuh situasi aman untuk belajar. Beta (saya) masih kecil waktu konflik di Ambon, tetapi beta pung (kakak-kakak saya) seng (tidak) bisa kuliah baik-baik. Jadi, menurut beta (saya), para pemuda seng (tidak) mau konflik lagi karena dong (mereka) mau masa depan yang baik. Karena itu, mereka tidak mau merusak hubungan yang sudah membaik ini." ${ }^{27}$

Pandangan yang melihat keinginan para pemuda untuk mendapatkan masa depan yang baik sebagai salah satu faktor pendorong hubungan yang baik antara umat Islam dan Kristen, menegaskan kesadaran mereka bahwa konflik sosial tidak hanya menghancurkan rumah mereka, tetapi juga menghancurkan secara total masa depan mereka. Konflik sosial merampas hak mereka untuk mendapatkan kenyamanan belajar. "Jang lai (jangan lagi); tidak ada guna konflik. Hidup kita rusak dan tidak ada masa depan," kata Marco. ${ }^{28}$ Bagi orang Maluku, juga masyarakat kota Ambon, pernyataan jang lai (jangan lagi) merupakan ekspresi yang sangat dalam akan harapan agar sesuatu yang buruk tidak lagi terjadi dalam kehidupan mereka. Pernyataan itu tidak hanya mengajak orang lain untuk berhenti

${ }^{27}$ Deny (24 tahun), Wawancara, Hunut-Durian Patah-Ambon, 7 Juli 2016.

${ }^{28}$ Marco (29 tahun), Wawancara, Kudamati-Ambon, 24 Juni 2016. 
melakukan tindakan negatif, tetapi merupakan komitmen diri sendiri untuk tidak lagi melakukan yang buruk. Pernyataan seperti ini sangat penting, sebab terlahir dari pengalaman akan dampak negatif dari konflik sosial yang terjadi dalam suatu masyarakat, dalam hal ini di kota Ambon. Konflik sosial berbasis agama mematikan kehidupan manusia dalam seluruh aspeknya.

Selain faktor ekonomi dan keinginan mendapatkan masa depan yang baik, seorang pemuda mengatakan bahwa sikap keterbukaan antara dua pihak menjadi salah satu faktor yang sangat menentukan rekonsiliasi di antara mereka. "Waktu konflik terjadi, orang Islam dan Kristen saling curiga. Kecurigaan itu juga yang menyebabkan konflik berlangsung lama. Tetapi ketika orang Islam dan Kristen saling terbuka, mereka sadar bahwa isu-isu yang beredar tidak betul." ${ }^{29}$ Pandangan yang sama disampaikan oleh pemuda lain demikian "Orang Ambon ini cepat emosi. Dengar isu, tidak cek kebenaran, tetapi langsung bertindak. Padahal, waktu kedua komunitas mulai saling cek informasi, mereka sadar bahwa itu provokasi. Jadi, saling memberi informasi itu penting." ${ }^{30}$ Dari pandangan kedua pemuda ini, dapat dikatakan bahwa mereka melihat keterbukaan sebagai salah satu faktor yang sangat diperlukan pada saat konflik sosial terjadi. Tidak hanya pada saat konflik sosial, keterbukaan sangat diperlukan dalam kehidupan bermasyarakat, terutama dalam kehidupan masyarakat majemuk. Jika tidak ada keterbukaan, maka yang berkembang adalah sikap saling mencurigai. Sikap curiga merupakan lahan subur berkembangnya provokasi yang bertujuan menghancurkan kebersamaan hidup masyarakat majemuk. Dengan keterbukaan, setiap orang tidak dicurigai dan mencurigai, tetapi bersama-sama berbagi rasa dan pengalaman, baik yang buruk maupun yang menyenangkan. Inilah spirit dari slogan yang cukup terkenal di Maluku, Ale Rasa Beta Rasa atau Saya rasakan apa yang Anda rasakan.

${ }^{29}$ Piet (35 tahun), Wawancara, Waylela-Ambon, 24 Juli 2016.

${ }^{30}$ Madi (32 tahun), Wawancara, Wainitu-Ambon, 28 Juli 2016. 
Menarik bahwa agama juga dilihat dan diakui sebagai faktor yang mempengaruhi terbentuknya hubungan baik antara Islam dan Kristen di kota Ambon. Hal ini dikatakan oleh Marco, "Untuk bisa menjadi lebih baik lagi, kedua bela pihak harus bisa tahu dan menjalankan ajaran agama masing-masing. Karena tidak ada agama yang mengajarkan pemeluknya untuk melakukan kejahatan. Jadi, kalau kedua bela pihak menjalankan ajaran agama dengan benar, maka tidak lagi ada kekacauan di kota Ambon." ${ }^{31}$ Agama dilihat sebagai salah satu prinsip yang mengajarkan tentang kebaikan. Kebaikan itu antara lain terwujud dalam hidup saling melindungi dan menghargai. Prinsip inipun dibicarakan oleh Suseno bahwa "agama hanya mempunyai masa depan apabila ia dapat memancarkan kebaikan belas kasihan dan kebesaran hati Ilahi secara meyakinkan ke dalam masyarakat." ${ }^{32}$ Pikiran ini memberi pesan kepada seluruh umat beragama bahwa ajaran agama itu tidak hanya harus diketahui tetapi juga harus dilakukan. Umat beragama harus mewujudkan ajaran agama dalam hidup mereka. Kesadaran ini akan dengan sendirinya mencegah umat beragama melakukan tindakan yang bertentangan dengan ajaran agama, termasuk "membenci dan menghancurkan" umat beragama lain.

\section{Proses Bersama Menyembuhkan Luka Sejarah}

Proses-proses rekonsiliasi yang sedang dibangun oleh umat Islam dan Kristen di kota Ambon menunjukkan bahwa masyarakat kota ini sedang menata kehidupan mereka menjadi lebih baik. Mereka yang memiliki pandangan positif tentang realita hubungan umat Islam dan Kristen di kota Ambon merujuk kepada aktifitas sosial maupun aktifitas keagamaan yang dilakukan secara bersama-sama. Nampak di sini, telah terjadi perubahan dari sikap membenci dan mengucilkan kepada sikap merangkul, menghargai, dan menghormati. Oleh karena itu, sekalipun umat Islam dan umat Kristen hidup tersegregasi dalam wilayah-wilayah pemukiman mereka sendiri-sendiri, ada upaya untuk berjumpa dan

\footnotetext{
${ }^{31}$ Marco (34 tahun), Wawancara, Kudamati-Ambon, 25 Juni 2016.

${ }^{32}$ Suseno, "Keagamaan Masa Depan," 62.
} 
berinteraksi dalam kegiatan-kegiatan sosial dan keagamaan, seperti yang disebutkan para pemuda. Hal ini merupakan satu indikasi bahwa baik umat Islam maupun umat Kristen telah melewati masa-masa sulit akibat konflik sosial itu. Mereka telah berhasil mengelola rasa sakit dan dendam akibat kehilangan orang yang dicintai dan kehilangan rumah serta harta benda. Mereka bisa mencapai tahap itu karena mereka telah berdamai dengan pengalaman hidup mereka, yang pahit dan menyakitkan.

Berdamai dengan pengalaman masa lampau yang menyakitkan bukan berarti mereka tidak lagi mengingat peristiwa-peristiwa pahit yang mereka alami. Berdamai dengan pengalaman masa lampau yang menyakitkan berarti menerima rasa sakit itu sebagai suatu fakta sejarah hidup yang tidak mungkin dapat diubah. Tetapi, rasa sakit itu mendorong mereka untuk berupaya memperbaiki hal-hal yang menyebabkan konflik sosial itu terjadi dalam kehidupan mereka sekarang. Dengan berdamai dengan masa lampau, rasa sakit itu tidak akan melahirkan kebencian dan dendam. Sebaliknya, rasa sakit itu mendorong upaya-upaya untuk mencegah terulangnya rasa sakit itu, baik kepada diri mereka sendiri maupun generasi berikutnya. Ini bukan merupakan suatu proses hidup yang mudah. Mereka harus mampu mengelola ingatan mereka terhadap peristiwa-peristiwa yang menyakitkan itu. Tentang hal mengingat peristiwa-peristiwa traumatis, dalam artikelnya yang berjudul Mengingat Trauma Landasan Teologi Perasaan (Emosi) Bagi Penanganan Pastoral Korban Peristiwa Traumatis, Pakpahan, seorang teolog dari Sekolah Tinggi Filsafat Teologi Jakarta, menulis:

"Masa lalu yang diingat dalam komunitas disatukan dalam ingatan kolektif. Ketika ingatan akan emosi yang menyakitkan diwariskan kepada generasi penerus, tanpa menjelaskan ingatan akan peristiwa yang terjadi, sebuah komunitas sedang mewariskan ingatan emosi negatif. Sebuah kelompok dapat mengingat perasaan benci dan marah mereka terhadap kelompok lain, lalu bertindak berdasarkan ingatan itu, tanpa benar-benar tahu apa yang sebenarnya terjadi dalam ingatan peristiwa yang lalu. Identitas kolektif dan individu 
yang berangkat dari ingatan seperti itu dapat menjadi bahaya membuka sebuah luka tanpa harapan untuk pemulihan ingatan." ${ }^{33}$

Pandangan pakpahan ini hendak menegaskan bahwa dalam hal mengingat peristiwa traumatis dan pewarisan ingatan itu kepada generasi muda, maka yang harus diwariskan adalah ingatan tentang peristiwa dan bukan ingatan akan emosi atau perasaan tentang peristiwa itu. Artinya, dalam mewariskan ingatan akan suatu peristiwa, emosi atau perasaan yang dialami pada saat peristiwa traumatis terjadi jangan diwariskan sebagai ingatan. Sebab, perasaan atau emosi adalah motor yang sangat kuat menggerakan perilaku manusia. ${ }^{34} \mathrm{Jadi}$, jika ingatan terhadap emosi atau perasaan sakit, marah, dan dendam yang terwarisi, maka akan menggerakan keinginan membalas dendam.

Perjumpaan dan kreasi hidup yang dilakukan secara bersama-sama dalam kehidupan umat Islam dan Kristen di kota Ambon, merupakan bukti kesadaran bersama mereka bahwa menyembuhkan luka sejarah yang dialami mereka tidak dapat dilakukan oleh satu pihak. Kesediaan untuk menerima orang yang melukai, mesti juga menjadi kesediaan orang yang dilukai. Dengan semikian, mereka bersama-sama bergerak meninggalkan rasa sakit dan dendam, memasuki tekad berjuang menciptakan perdamaian untuk dialami bersama. Untuk kepentingan ini, maka cara berpikir kelompok sendiri, "kita", disucikan dan makin disucikan, sedangkan kelompok lain, "mereka", dilecehkan dan disetankan ${ }^{35}$ sudah seharusnya ditransformasi.

Perjuangan menciptakan kebersamaan dalam masyarakat yang hidup dalam realita plural sepatutnya menjadi agenda bersama. Agenda itu antara lain adalah, "Bagaimana menciptakan sebuah hubungan yang harmonis, terutama bagi para pemeluk agama yang berbeda. Kerukunan

\footnotetext{
${ }^{33}$ Binsar J. Pakpahan, "Mengingat Trauma Landasan Teologi Perasaan (Emosi) Bagi Penanganan Pastoral Korban Peristiwa Traumatis," dalam Seputar Pelayanan Pastoral, Panitia Emiritasi Pendeta Daniel Susanto (Jakarta: GKI menteng, 2016), 196.

${ }^{34}$ Ibid., 204.

${ }^{35}$ Ihsan Ali-Fauzi, “Ambiguitas Agama sebagai Peluang dalam Menciptakan Perdamaian Agama," Religio: Jurnal Studi Agama-agama 5, no. 2 (September 2015): 235.
} 
antar umat beragama menjadi tujuan utama, karena tidak dipungkiri lagi bahwa perbedaan agama terkadang sering memunculkan konflik". ${ }^{36}$ Menyadari akan hal ini, maka semua agama melihat dialog agama sebagai salah satu agenda yang harus selalu dibangun.

\section{Dialog Agama}

Pada umumnya, persoalan muncul dalam hubungan antarumat beragama, sebab umat beragama tidak mampu menghormati dan menerima perbedaan-perbedaan yang ditemukannya dalam agama yang dianut orang lain. Perbedaan-perbedaan yang ada dalam agama, sangat sering dijadikan sebagai pegangan atau alasan untuk menolak keberadaan agama-agama lain. Padahal, jika masing-masing umat beragama itu mempelajari dengan baik agamanya, mereka akan menemukan bahwa dalam kitab sucinya, mereka dituntut untuk menghormati perbedaanperbedaan itu. Dengan kata lain, pada dasarnya semua agama mengajarkan tentang penghargaan terhadap agama orang lain. Oleh karena itu, keberagaman atau kemajemukan agama tidak harus dilihat sebagai ancaman bagi agama yang dianut seseorang. Oleh karena keberagaman itu, maka dibutuhkan dialog antarumat beragama, termasuk dialog antara umat Islam dengan umat Kristen.

Dialog antarumat beragama bukan hanya saling memberi informasi tentang mana yang sama dan mana yang berbeda antara ajaran agama yang satu dengan lainnya, bukan merupakan suatu usaha agar orang yang berbicara menjadi yakin akan kepercayaannya, dan menjadikan orang lain mengubah agamanya kepada yang ia peluk. Dialog tidak dimaksudkan untuk konversi, yaitu untuk mengusung orang lain supaya menerima kepercayaan yang ia yakini, sekalipun konversi semacam ini menggembirakan orang yang beragama lain. Dialog agama bukan suatu studi akademis terhadap agama, juga bukan merupakan usaha untuk menyatukan semua ajaran agama menjadi satu. Dialog antarumat beragama juga bukan suatu usaha untuk membentuk agama baru yang

\footnotetext{
${ }^{36}$ Lailatuz Zuhriyah, "Teologi Konvergensi dan Kerukunan Antar Umat Beragama," Religio: Jurnal Studi Agama-agama 4, no. 1 (Maret 2014): 79.
} 
dapat diterima oleh semua pihak. Bukan berdebat adu argumentasi antarumat beragama, hingga ada orang yang menang dan ada yang kalah. Dialog bukanlah suatu usaha untuk meminta pertanggungjawaban kepada orang lain dalam menjalankan agamanya. Tetapi dialog berupaya memberikan pemahaman dan pengertian tentang ajaran dan kehidupan. ${ }^{37}$

Dialog dilakukan bukan untuk meniadakan perbedaan-perbedaan yang ada, tetapi untuk membangun pengertian terhadap perbedaanperbedaan agama yang pada prinsipnya tidak bisa ditolak. Melalui dialog, akan terbangun sikap menghargai dan menerima perbedan-perbedaan itu, sehingga dialog menolong umat beragama untuk membangun hidup dalam perdamaian yang sejati. Dari pandangan Kristen, dialog merupakan perwujudan dari sikap keramahtamaaan (bospitality) yang harus dibangun dalam kehidupan gereja. ${ }^{38}$ Selain itu, dialog merupakan cara setiap agama mengakui dan menghormati keunikan atau keberlainan masing-masing pihak tanpa saling menilai atau menghakimi. ${ }^{39}$ Oleh karena itu, dalam dialog diperlukan kesadaran bahwa "kita semua berbicara sesama kita tentang masalah kita. Di sini para peserta dialog menyatu dalam sprit kekitaan dan kebersamaan tanpa adanya kekhawatiran dan kecurigaan satu sama lain.. ${ }^{30}$

Dialog membantu komunitas untuk mampu melihat diri mereka sendiri melalui perspektif pihak lain dan untuk memperoleh pandanganpandangan baru atas agama atau keyakinan yang lain sebagaimana agama atau keyakinan mereka sendiri. ${ }^{41}$ Dengan demikian, dialog bukan merupakan pertimbangan praktis tetapi dialog adalah ekspresi iman yang

\footnotetext{
${ }^{37}$ Lathifatul Izzah, "Melihat Potret Harmonisasi Hubungan Antar Umat Beragama," Religi: Jurnal Studi Agama-Agama 4, no. 1 (Januari 2013): 7-8, https://doi.org/10.14421/ rejusta.2013.0901-01.

${ }^{38}$ Pim Valkenberg, Sharing Lights On the Way to God: Muslim-Christian Dialogue and Theology in the Context of Abrahamic Partnership (Amsterdam-New York: Rodopi, 2006), 9.

${ }^{39}$ Olaf Schumann, Dialog Antarumat Beragama: Membuka Babak Baru Hubungan Antarumat Beragama (Jakarta: BPK Gunung Mulia, 2009), 300.

${ }^{40}$ Taslim H.M. Yasin, "Membangun Hubungan antar Agama Mewujudkan Dialog dan Kerjasama," Jurnal Substantia 12, no. 1 (April 2011): 88.

${ }^{41}$ Tore Lindholm, Kebebasan Beragama atau Berkeyakinan: Seberapa Jaub? Sebuah Referensi tentang Prinsip-Prinsip dan Praktek (Yogyakarta: Kanisius, 2010), x.
} 
sejati dari semua umat beragama apapun agamanya. Ini seharusnya antara lain yang menjadi prinsip dasar dari semua dialog antaragama yang dilakukan. Prinsip mendasar dialog seperti ini yang juga dikatakan oleh Izzah, "Dialog antarumat beragama juga diartikan sebagai bahasa kasih Tuhan yang diekspresikan dalam hidup. Dialog merupakan pertemuan hati dan pikiran antarpemeluk agama yang berbeda. Dengan demikian, hal itu dapat membawa para pendialog lebih dekat kepada misteri Tuhan. Kecenderungan dialog itu sesungguhnya tidak berhenti hanya sebagai suatu gaya hidup (life-style), tetapi juga dipikirkan untuk menjadi suatu pandangan hidup (way of life)." 42

Meskipun demikian, dialog agama hanya dapat dilakukan ketika umat beragama menjadi umat yang beriman secara matang dan dewasa. Artinya, semua umat beragama tidak memandang agama lain sebagai ancaman atau musuh yang harus dihancurkan. Dialog antaragama mengisyaratkan kemauan merangkul dalam perbedaan sehingga perbedaan itu tidak dilihat sebagai ancaman yang harus dihindari atau ditolak, tetapi perbedaan itu dihargai dan dihormati. Penerimaan dan penghormatan terhadap perbedaan akan membentuk kemauan untuk hidup berdampingan dengan siapapun yang berbeda dengan kita. Dalam hidup berdampingan itu, identitas diri itu tidak akan hilang, tetapi semakin diperkuat oleh keberadaan "yang lain itu", sebab identitas kita dibentuk juga oleh orang lain yang dengannya kita berinteraksi. ${ }^{43}$

Pandangan Volf memberi inspirasi bagi seluruh umat beragama, terutama umat beragama di Indonesia yang terkenal dengan kemajemukannya. Sebagai masyarakat majemuk, bangsa Indonesia tidak mungkin lagi hidup dalam isolasi dan eksklusivisme. Pada pihak lain, kita juga tidak mungkin memaksakan kesatuan yang monolitis. Kita saling tergantung satu pada yang lain. Memperhatikan kepentingan yang lain berarti memperhatikan kepentingan sendiri. Kepentingan sendiri harus

\footnotetext{
${ }^{42}$ Izzah, "Melihat Potret Harmonisasi," 9.

${ }^{43}$ M. Volf, "A Theology of Embrace for a World of Exclusion," dalam Exploration in Reconciliation: New Diraction in Theology, eds. Tombs D dan Liechty J. (Aldershot: Ashgate, 2006), 28.
} 
diperjuangkan dalam kerangka kepentingan bersama. Kita mempunyai identitas sendiri-sendiri yang saling berbeda tetapi kita juga terikat satu sama lain oleh satu kemanusiaan bersama. ${ }^{44}$

Dalam masyarakat majemuk, dialog agama diperlukan untuk membangun sikap toleran antaragama. Pembentukan sikap toleran seharusnya tidaklah sulit, sebab pada prinsipnya semua umat beragama mengakui bahwa agama ada untuk memberikan ketulusan, kejujuran, dan keadilan sejati bagi umatnya. Penempatan agama seperti itulah yang seharusnya mewarnai keseharian umat beragama dalam hubungannya dengan pemeluk agama lain juga. ${ }^{45}$ Namun, berbagai peristiwa yang teramati dalam kehidupan bermasyarakat menunjukkan fakta terbalik dari prinsip umum di atas. Agama masih menjadi alasan orang melakukan tindakan-tindakan kekerasan, bahkan agama dijadikan sebagai sumber atau rujukan pembenaran bagi tindakan pembunuhan yang dilakukan. Jadi, dapat dikatakan bahwa masih ada orang yang mempraktikkan sikap hidup intoleran dari pada sikap hidup toleran. Oleh karena itu, prinsip toleransi kepada umat beragama lain masih tetap menjadi hal yang harus terus digumuli dan dibangun oleh seluruh umat beragama.

Toleransi bukanlah sikap hidup yang bertentangan dengan iman pemeluk suatu agama. Toleransi memiliki keterkaitan yang erat dengan sikap beriman dari umat beragama, termasuk pemeluk agama Islam dan pemeluk agama Kristen. Toleransi mengekpresikan fungsi terdalam dari iman, yaitu menolong manusia menjadi manusia yang mengakui kebersamaannya dengan sesamanya dalam segala perbedaan yang mereka miliki, termasuk perbedaan iman atau agama. Dalam hal ini, iman menolong manusia keluar dari diri sendiri untuk bertemu dan bergaul dengan orang lain. Dengan demikian, sikap toleransi merupakan ekspresi iman yang sejati dari umat beragama, apapun agamanya. Toleransi menunjukkan kedewasaan pemeluk agama dalam menjalani kehidupan keagamaanya karena pemeluk agama itu mampu membangun kerukunan

${ }^{44}$ Martin Sinaga, Pergulatan Kehadiran Kristen di Indonesia: Teks-Teks Terpilib Eka Darmaputera (Jakarta: BPK Gunung Mulia, 2005), 135-136.

${ }^{45}$ Lindholm, Kebebasan Beragama, xi. 
hidup dengan orang lain. Kerukunan sejati hanya mungkin dibangun di atas fondasi iman yang kokoh yang membuahkan ketulusan dan kejujuran.

Dalam kaitan dengan masalah hubungan antarpemeluk agama, mungkin formula berikut dapat disepakati, "berbeda dalam persaudaraan dan persaudaraan dalam perbedaan". ${ }^{46}$ Prinsip inilah yang secara minimal, sementara dibangun oleh umat Islam dan Kristen dalam kehidupan mereka di kota Ambon. Dialog agama sangat dibutuhkan, terutama di daerah yang pernah mengalami konflik sosial berbasis agama, sebab konflik sosial itu telah menjadi luka sejarah, dan ingatan tentang konflik itu akan diturunalihkan, dengan pesan-pesan yang berbeda. Melalui dialog antaragama, teruatama antara Islam dan Kristen di kota Ambon, penerimaan dan penyembuhan terhadap luka sejarah itu dapat selalu dibangun secara baik dan benar.

\section{Penutup}

Dari kajian yang telah dilakukan terhadap bagaimana umat Islam dan Kristen di kota Ambon membangun rekonsiliasi di antara mereka, dapat disimpulkan bahwa pada umumnya rekonsiliasi itu dibangun oleh masyarakat akar rumput. Oleh karena itu, rekonsiliasi itu dilakukan melalui cara-cara yang kecil dan sederhana, tetapi berkaitan secara langsung dengan kebutuhan untuk memperbaiki hubungan di antara umat Islam dan Kristen yang rusak akibat konflik sosial tahun 19992004. Jadi, rekonsiliasi Islam-Kristen terjadi di kota Ambon, baik melalui perjumpaan sehari-hari, dalam interaksi yang saling menghidupkan, maupun melalui aktifitas-aktifitas keagamaan. Rekonsiliasi di antara mereka dapat terjadi, setelah baik umat Islam maupun Kristen menyadari bahwa konflik sosial berbasis agama tidak pernah memberi dampak positif bagi kehidupan mereka. Konflik sosial berbasis agama justru menghancurkan prinsip-prinsip kehidupan agama secara mendasar. Dengan kata lain, rekonsiliasi terjadi dari kesadaran bersama tentang

${ }^{46}$ Ibid., xii. 
kebutuhan untuk hidup berdampingan secara damai demi masa depan yang lebih baik.

Proses-proses rekonsiliasi itu juga merupakan proses bersama menyembuhkan luka sejarah yang ditinggalkan oleh konflik sosial itu, sebab konflik sosial berbasis agama itu telah meninggalkan berbagai pengalaman buruk dan pahit, tidak saja bagi generasi yang terlibat langsung dan mengalami konflik sosial itu, tetapi juga bagi generasi mendatang yang sama sekali tidak mengalami peristiwa itu. Melalui rekonsiliasi Islam-Kristen dan dialog agama, ingatan terhadap konflik sosial berbasis agama itu diarahkan secara baik, sehingga dendam dan kebencian dapat ditransformasi menjadi damai dan cinta. Demikian juga ketakutan dan penolakan ditransformasi menjadi saling menerima dan merangkul.

\section{Daftar Pustaka}

Al-Qurtuby, Sumanto. 'Pluralisme, Dialog, dan Peacebuilding Berbasis Agama di Indonesia." Dalam Merayakan Kebebasan Beragama. Ed. Elza Peldi Taher. Jakarta: ICRP \& Buku Kompas, 2009.

Dubut, Darius. "Dari Perbedaan Menuju kebersamaan," dalam Merayakan Kebebasan Beragama: Bunga Rampai 70 Tahun Djohan Effendi Ed. Elza Peldi Taher. Jakarta: ICRP dan Kompas, 2009.

Effendi, Djohan. Pluralisme dan Kebebasan Beragama. Yogyakarta: Interfidei, 2011.

Fauzi, Ihsan Ali. "Ambiguitas Agama sebagai Peluang dalam Menciptakan Perdamaian Agama." Religio: Jumal Studi Agama-agama 5, no. 2 (September 2015): 233-244.

Fromn, Ercih. Akar Kekerasan: Analisis Sosio-Psikologis atas Watak Manusia. Yogyakarta: Pustaka Pelajar, 2010. 
Haryanto, Ignatius, dan Pax Benedanto. Terbuka terbadap Sesama Umat Beragama. Yogyakarta: Kanisius, 2004.

Izzah, Lathifatul. "Melihat Potret Harmonisasi Hubungan Antar Umat Beragama." Religi: Jurnal Studi Agama-agama 4, no. 1 (Januari 2013): 1-22, https://doi.org/10.14421/rejusta.2013.0901-01.

Khotimah. "Dialog dan Kerukunan Antar Umat Beragama." Jurnal Ushuluddin 17, no. 2 (Juli 2001): 214-224, http//dx.doi.org/10.24014/jush.v17i2.693.

Lindholm, Tore. Kebebasan Beragama atau Berkeyakinan: Seberapa Jauh? Sebuah Referensi tentang Prinsip-Prinsip dan Praktek. Yogyakarta: Kanisius, 2010.

Pakpahan, Binsar J. "Mengingat Trauma Landasan Teologi Perasaan (Emosi) Bagi Penanganan Pastoral Korban Peristiwa Traumatis." Dalam Seputar Pelayanan Pastoral. Panitia Emiritasi Pendeta Daniel Susanto. Jakarta: GKI menteng, 2016.

Schumann, Olaf. Dialog Antar Umat Beragama. Jakarta: BPK Gunung Mulia, 2009. - Agama-agama: Kekerasan dan Perdamaian. Jakarta: BPK Gunung Mulia, 2011. - Menghadapi Tantangan, Memperjuangkan Kerukunan. Jakarta: BPK Gunung Mulia, 2006. - Dialog Antarumat Beragama: Membuka Babak Baru Hubungan Antarumat Beragama. Jakarta: BPK Gunung Mulia, 2009.

Sinaga, Martin. Pergulatan Kehadiran Kristen di Indonesia: Teks-Teks Terpilih Eka Darmaputera. Jakarta: BPK Gunung Mulia, 2005. 
Suseno, Frans Magnis. "Keagamaan Masa Depan." Dalam Spiritualitas Agama-agama untuk Keadilan dan Perdamaian. Ed. Indro Suprobo. Yogyakarta: Interfidei, 2011.

Umar, Nasaruddin. "Interfaith Dialog dalam Mengembangkan Kehidupan Beragama yang Harmoni dan Damai." Jurnal Bimas Islam 6, no. 3 (2013).

Valkenberg, Pim. Sharing Lights On the Way to God: Muslim-Christian Dialogue and Theology in the Context of Abrahamic Partnership. Amsterdam-New York: Rodopi, 2006.

Volf, M. "A Theology of Embrace for a World of Exclusion." Dalam Exploration in Reconciliation: New Diraction in Theology. Eds. Tombs D dan Liechty J. Aldershot: Ashgate, 2006.

Yasin, Taslim H.M. "Membangun Hubungan antar Agama Mewujudkan Dialog dan Kerjasama." Jurnal Substantia 12, no. 1 (April 2011): 8591.

Zuhriyah, Lailatuz. "Teologi Konvergensi dan Kerukunan Antar Umat Beragama," Religio: Jurnal Studi Agama-agama 4, no. 1 (Maret 2014): 78-95. 